\title{
Identifying the key genes and pathways in the progression of hepatitis $C$ virus induced hepatocellular carcinoma using a systems biology approach
}

\author{
Siyuan Zheng ${ }^{1}$, Zhongming Zhao ${ }^{1,2^{*}}$ \\ From $10^{\text {th }}$ Annual UT-ORNL-KBRIN Bioinformatics Summit 2011 \\ Memphis, TN, USA. 1-3 April 2011
}

\section{Background}

Incidence of hepatitis $\mathrm{C}$ virus (HCV) induced hepatocellular carcinoma (HCC) has been increasing in many developed countries including the United States and Europe during the recent years. Although many efforts have been made to understand the pathogenesis, the picture of its progression still remains elusive.

\section{Materials and methods}

We developed a systematic approach to identify deregulated biological networks in HCC by integrating gene expression profiles [1] with high-throughput proteinprotein interaction data [2]. Samples were grouped into five disease stages including normal, cirrhotic, dysplastic, early and advanced HCC. For each pair of consecutive stages, we compared gene expressions and then mapped these measures to the protein interaction network.
Responsive subnetworks were then identified from these node weighted networks. The searching algorithm is adapted from a previous study [3], which expands the seed graphs under constrains of several parameters.

\section{Results}

Four networks were identified including precancerous networks (normal-cirrhosis and cirrhosis-dysplasia) and cancerous networks (dysplasia-early HCC, earlyadvanced HCC). A summary of these networks is shown in Table 1. An independent dataset was used for network validation. Statistical significance of these networks was assessed within three hypotheses. Little overlap was observed between precancerous and cancerous networks, in contrast to a substantial overlap within precancerous or cancerous networks. Network functions were annotated with Gene Ontology biological process

Table 1 Overview of the responsive networks.

\begin{tabular}{ccccc}
\hline Network & \#Genes & \#Interactions & \#DEGs $^{*}$ & \#Hub interactions $^{\dagger}$ \\
\hline Normal- cirrhosis & 55 & 67 & $53(96.3 \%)$ & $42(62.7 \%)$ \\
Cirrhosis- dysplasia & 38 & 50 & $37(97.4 \%)$ & $35(70.0 \%)$ \\
Dysplasia -early HCC & 60 & 65 & $53(88.3 \%)$ & $37(56.9 \%)$ \\
Early- advanced HCC & 68 & 98 & $59(86.8 \%)$ & $79(80.6 \%)$ \\
\hline
\end{tabular}

"Differentially expressed genes (DEGs) were identified as genes with up or down regulation fold change $\geq 2$ and student t test $P$ value $\leq 0.01$.

${ }^{\dagger}$ Hub interaction number refers to the total number of interactions involving hub genes.

${ }^{\ddagger} \mathrm{Hub}$ genes were defined to have at least 5 interactions in each network.

\footnotetext{
* Correspondence: zhongming.zhao@vanderbilt.edu

'Department of Biomedical Informatics, Vanderbilt University Medical Center,

Nashville, TN, 37232, USA

Full list of author information is available at the end of the article
} 
using hypergeometric distribution based enrichment analysis. Significant functions were then assembled into a module map in temporal order. The apoptosis gene ZBTB16 was highlighted by examining the module map, which shows a negative expression pattern with $c$-myc. Network analysis led to the identifications of key genes and pathways by developmental stage, such as $L C K$ signaling pathways in cirrhosis, MMP genes and TIMP genes in dysplastic liver, and $C D C 2$-mediated cell cycle signaling in early and advanced HCC. $C D C 2$, a cell cycle regulatory gene, is particularly interesting because it is a hub protein of the module that shows correlative pattern with cancer progression.

\section{Conclusions}

Our study uncovers a temporal spectrum of functional deregulation and prioritizes key genes and pathways in the progression of HCV induced HCC. Despite the confirmation of much knowledge in the pathogenesis of this disease, these findings also provide additional insights for further investigations.

\section{Acknowledgements}

We thank Drs. Scott Hiebert, William Tansey, Jingchun Sun and Peilin Jia and Mr. Jeffery Ewers for helpful discussions.

\section{Author details}

'Department of Biomedical Informatics, Vanderbilt University Medical Center, Nashville, TN, 37232, USA. ${ }^{2}$ Department of Cancer Biology, Vanderbilt University Medical Center, Nashville, TN, 37232, USA.

Published: 5 August 2011

\section{References}

1. Wurmbach E, Chen YB, Khitrov G, Zhang W, Roayaie S, Schwartz M, Fiel I, Thung S, Mazzaferro V, Bruix J, et al: Genome-wide molecular profiles of HCV-induced dysplasia and hepatocellular carcinoma. Hepatology (Baltimore, Md) 2007, 45(4):938-947.

2. Wu J, Vallenius T, Ovaska K, Westermarck J, Makela TP, Hautaniemi S: Integrated network analysis platform for protein-protein interactions. Nature methods 2009, 6(1):75-77.

3. Chuang HY, Lee E, Liu YT, Lee D, Ideker T: Network-based classification of breast cancer metastasis. Molecular systems biology 2007, 3:140.

doi:10.1186/1471-2105-12-S7-A4

Cite this article as: Zheng and Zhao: Identifying the key genes and pathways in the progression of hepatitis $C$ virus induced hepatocellular carcinoma using a systems biology approach. BMC Bioinformatics 2011 12(Suppl 7):A4.

\section{Submit your next manuscript to BioMed Central and take full advantage of:}

- Convenient online submission

- Thorough peer review

- No space constraints or color figure charges

- Immediate publication on acceptance

- Inclusion in PubMed, CAS, Scopus and Google Scholar

- Research which is freely available for redistribution

Submit your manuscript at www.biomedcentral.com/submit
C Biomed Central 